\title{
MAKING SENSE OF MESNE PROFITS: CAUSES OF ACTION
}

\author{
CHARLES MITCHELL* AND LUKE ROSTILL**
}

\begin{abstract}
The article examines a series of cases spanning a 250-year period in which the courts have awarded "mesne profits" against defendants who have occupied claimants' land. The article argues (a) that various causes of action are disclosed by the facts of cases in which such awards have been made, (b) that these causes of action have changed as the law of obligations has evolved, (c) that modern courts often do not consider what causes of action are disclosed by the facts of "mesne profits cases", $(d)$ that this is unfortunate because practical consequences can flow from categorising the cases in one way or another, and (e) that the resolution of future "mesne profits cases" will become more just and more transparent when it is understood that their facts may variously disclose causes of action in tort, contract or unjust enrichment.
\end{abstract}

KEYWORDS: mesne profits; damages; remedies; trespass to land; tolerated trespassers; landlord and tenant; unjust enrichment.

\section{INTRODUCTION}

"Mesne" is an old French word that meant "intermediate". It gives us the modern expression "in the meantime": "during a period between now and a future date". It also gives us "mesne profits": "benefits accruing during a period between two dates". Originally, an "action for mesne profits" was a trespass action which lay where one person $(\mathrm{C})$ had the right to exclusive possession of land against another person (D) who had occupied the land in breach of C's right. Damages were assessed by reference to the profits made by $\mathrm{D}$ from using the land between the date when the trespass began and the date when it ended. Thus the pleading used in such actions included a declaration that "the defendant broke and entered the premises, and staid and continued therein, and ejected the plaintiff, and kept him out of possession, and during that time took the profits to himself, whereby the plaintiff, during that time, lost all the issues and profits thereof". ${ }^{1}$ Surveying the history of actions for mesne profits in a recent case, ${ }^{2}$ members of the New South Wales Court of Appeal have said that the wording of this declaration reflected a conception of "mesne profits" that the point of these was to make D pay over his gains. Another reading is possible, however, namely that they were understood to be compensatory, their point having been to compensate $\mathrm{C}$ for loss that was measured by quantifying D's profits, on the assumption that $\mathrm{C}$ would have made these profits himself if he had been in possession of the land.

\footnotetext{
* Q.C. (Hon.), F.B.A., Professor of Law, University College London.

** Fellow and Tutor in Law at Trinity College, Oxford and Associate Professor of Property Law, Oxford University. For their comments on drafts we thank the anonymous CLJ referees, Toby Boncey, Jessica Hudson, Ben McFarlane, and members of the Oxford Property Law Discussion Group. For her research assistance we thank Neeva Desai.

${ }^{1}$ Dunn v Large (1783) 99 E.R. 683.

2 Sydney Local Health District v Macquarie International Health Clinic Pty Ltd [2020] NSWCA 274, at [89]-[93].
} 
It is impossible to tell from reading cases where $\mathrm{C}$ would have used the land in exactly the same way as D in fact used it, for example by farming it, whether awards of "mesne profits" were focussed on C's loss or D's gain, since these were the same. Whatever the courts' initial conception of "mesne profits" may have been, however, it is perfectly clear that nowadays this term is most commonly used to describe damages for trespass to land which aim to compensate $\mathrm{C}$ for loss; ${ }^{3}$ and that the loss for which compensatory damages are most usually sought is not a loss of the value of profits made by $\mathrm{D}$ from using the land (on the theory that $\mathrm{C}$ would have made the same amount), but a loss of the profits that $\mathrm{C}$ would have made if $\mathrm{C}$ had leased the property, either to $\mathrm{D}$ or to a third party (on the theory that this is what $\mathrm{C}$ would have done had it not been for D's wrongful occupation). ${ }^{4}$ It is true, however, that the term "mesne profits" is also used by modern courts to describe damages for trespass that are focussed on D's gain rather than C's loss; and to confuse matters further, the term is also used by modern courts to describe money awards in cases where no trespass has been committed because D has occupied land with C's permission. An example of this second usage occurs in Ministry of Defence $v$ Ashman, where Hoffmann L.J. said that

in the earlier cases it has not been expressly stated that a claim for mesne profit for trespass can be a claim for restitution. Nowadays I do not see why we should not call a spade a spade ... [and acknowledge that a claimant suing for the tort of trespass can elect for a] restitutionary remedy. ${ }^{5}$

An example of the third usage is provided by Dean and Chapter of Canterbury Cathedral $v$ Whitbread plc, where His Honour Judge Cooke, sitting as a deputy High Court judge, said that "the expression 'mesne profits' is frequently used loosely" to include money owed by a person who has occupied land with the owner's permission. ${ }^{6}$

These multiple usages of the term "mesne profits" have made it hard to see that such awards are now made in a variety of cases, the facts of which do not all disclose the same cause of action. Moreover, this problem has been exacerbated by the fact that "claims for mesne profits" are now most often made as part of residential tenancy possession actions by landlords whose main objective is to obtain orders for possession and for whom the winning of money awards is a secondary matter. In such proceedings, landlords often have little to gain from carefully analysing the basis on which their claims for "mesne profits" are made and the principles of assessment by which such awards are governed. The sums involved are often small and enforcing judgments against impecunious defendants can be more trouble than it is worth. Nor are landlords and their legal representatives encouraged to think closely about such matters by form $\mathrm{N} 119$, the standard form mandated for possession actions, ${ }^{7}$ which asks claimants to explain their proceedings to the court by selecting from these options in box $10:^{8}$

${ }^{3}$ See e.g. Ramzan v Brookwide Ltd [2011] EWCA Civ 985, [2011] 2 P. \& C.R. 22, at [44]; Network Rail Infrastructure Ltd v Handy [2015] EWHC 1175 (T.C.C.), at [32].

${ }^{4}$ As in e.g. Viscount Chelsea v Hutchinson (1996) 28 H.L.R. 17 (C.A.); Graves v Graves [2007] EWCA Civ 660, [2008] H.L.R. 10; Bindra v Chopra [2008] EWHC 1715 (Ch), [2008] 3 F.C.R. 341.

5 (1993) 66 P. \& C.R. 195, 201 (C.A.). See too Attorney-General v Blake [2001] 1 A.C. 268, 278 (H.L.).

${ }^{6}$ (1996) 72 P. \& C.R. 9, 13 (Ch.).

${ }^{7}$ By the Civil Procedure Rules, Practice Direction 55A, rule 55.3, para. 1.5.

${ }^{8}$ The form is published online at:

https://assets.publishing.service.gov.uk/government/uploads/system/uploads/attachment_data /file/732257/n119_web_0818_save.pdf 


\section{What the court is being asked to do}

10. The claimant asks the court to order that the defendant(s):

(a) give the claimant possession of the premises;

(b) pay the unpaid rent and any charge for use and occupation up to the date an order is made;

(c) pay rent and any charge for use and occupation from the date of the order until the claimant recovers possession of the property;

(d) pay the claimant's costs of making this claim.

The phrasing of this invites lawyers and judges to assume - and in practice they often do assume - that an amount awarded as a "charge for use and occupation" can safely be calculated in the same way as an amount awarded as "rent", without explaining the basis on which a landlord is entitled to claim such a "charge".

It may be that little turns on this in the context of small-stake residential property cases. However, these are not the only types of case in which claims for "mesne profits" are made. Where larger sums are involved there can be good financial reasons to think more carefully about the nature of such claims; and once one embarks on such an analysis, it quickly becomes clear that using a single term to describe different types of award makes it hard to understand why claimants are entitled to awards in different types of cases and what assessment principles apply in each type of case. This makes it hard for owners to identify and enforce their rights and for the courts to resolve disputes about land occupation in a fair and transparent way.

In this article and an associated article, we aim to make sense of the law governing "claims for mesne profits" by examining two questions: what causes of action underlie such claims and what remedies are awarded to successful claimants? We address the first question in this article and the second question in the other article. ${ }^{9}$ Our objective has been to identify the legal rules that affect the determination of "mesne profits cases", something which is far from obvious from a reading of many of the judgments, and which has required us to undertake interpretative doctrinal analysis of the case law. In other words, we have examined the facts, reasoning and results of cases where the courts have said that they are making "mesne profits awards" and from this information we have sought to deduce what legal rights claimants must have had for their claims to have succeeded on the facts of the cases, and what legal principles must have guided the courts in their assessments of remedy. Sometimes the courts have said what they think about these matters but often they have not, and in relation to such cases we have sought to make the implicit explicit.

Besides the practical considerations noted above, investigating these questions is also a valuable exercise because it affords an opportunity to consider the ways in which property rights can be supported by different parts of the law of obligations. It also makes it significantly easier to address a further set of questions one might also want to ask about the "mesne profits cases", namely whether the rights generated by the law of obligations for claimants in particular situations are normatively justified, and (separately but relatedly) whether the remedies awarded to claimants in these situations are normatively justified. However, we do not attempt to pursue the latter questions in either article, since they call for consideration of large questions about the moral foundations of private law claims and private law remedies which space does not permit us to address.

\footnotetext{
${ }^{9}$ C Mitchell and L Rostill, "Making Sense of Mesne Profits: Remedies” (forthcoming).
} 
In the present article, we argue that there are now three types of claim which can lead to awards of "mesne profits": some claims are founded on the tort of trespass, some on contract and some on unjust enrichment. One feature of our analysis is that in recent times "claims for mesne profits" and "claims for use and occupation" have become loosely assimilated and this has made it necessary to say something about the history of both types of claim and to refer to cases concerned with "claims for use and occupation" when explaining whether a "claim for mesne profits" should be classified as a claim in contract or as a claim in unjust enrichment. ${ }^{10}$ Another feature of our analysis is that it has important ramifications for the project of our second article, which discusses the principles on which awards are quantified. We subscribe to the view that the reasons why the law gives claimants particular rights "carry through" into the reasons why the holders of such rights are entitled to particular remedies. ${ }^{11}$ It follows that one cannot understand the principles on which any money award is quantified, including an award of "mesne profits", unless one first identifies the causes of action to which they respond. ${ }^{12}$

The present article proceeds as follows. In Part II we note that claims for "mesne profits" and claims for "the use and occupation of land" were once understood to be separate types of claim but have more recently been run together; we also note that claims for "use and occupation" have been described in cases where the parties cannot have had a contract as being "quasi-contractual", but that this description reflects an understanding of claims in unjust enrichment which has been rejected by senior appellate courts. We then identify three types of "mesne profits" claim: claims in tort (discussed in Part III), contract (in Part IV) and unjust enrichment (in Part V). Part VI discusses the reasons why it might matter which of these causes of action is relied on by a claimant seeking an award of "mesne profits". Part VII concludes.

\section{CLAIMS FOR “MESNE PROFITS” AND CLAIMS FOR “THE USE AND OCCUPATION OF LAND”}

As we have said, an action for "mesne profits" was initially understood to be an action for damages for the tort of trespass. When this was the prevailing understanding, claims for mesne profits were often contrasted with claims for "the use and occupation of land", a term that was used to describe a claim for the payment of money by D who had occupied land with C's permission. ${ }^{13}$ At one time, an action for "use and occupation" could be pleaded as an action in debt, ${ }^{14}$ in which case it would now be understood as an action to make D perform his primary payment obligation under a contract; but it was also possible to plead an action for "use and

\footnotetext{
${ }^{10}$ Two other claims can also lie in cases of overholding after the termination of a lease, both of some antiquity but both still with us: a claim for "double value" under section 1 of the Landlord and Tenant Act 1730 (4 Geo. 2, c. 28) and a claim for "double rent" under section 18 of the Distress for Rent Act 1737 (11 Geo. 2, c. 19). These have not been assimilated with "claims for mesne profits" and therefore fall outside the scope of our discussion.

${ }^{11}$ For an influential statement of this 'continuity thesis' see J Gardner, 'What is Tort Law For? Part 1. The Place of Corrective Justice' (2011) 30 Law and Philosophy 1.

${ }^{12}$ There is an ongoing scholarly debate about the basis on which awards of "mesne profits" are assessed when these are made as a remedy for the tort of trespass. We engage with this debate in our second article, although this is also concerned with other topics, including the basis on which "mesne profits" are assessed when awarded as a means of giving effect to a contractual promise to pay for the use of land, or as restitution for unjust enrichment.

13 e.g. Birch v Wright (1786) 99 E.R. 1148.

${ }^{14}$ e.g. Wilkins $v$ Wingate (1794) 101 E.R. 436; King v Fraser (1805) 102 ER 1320; Smith v Eldridge (1854) 139 E.R. 412; Bayley v Bradley (1884) 136 E.R. 932.
} 
occupation" as an assumpsit action, ${ }^{15}$ in which case there are two ways in which the action might now be understood in modern classificatory terms, depending on the facts: the purpose of the action could be to make D perform a contractual payment obligation or it could be to compel D to make restitution of an unjust enrichment. ${ }^{16}$

Nowadays claims are often made for "damages for use and occupation", ${ }^{17}$ suggesting yet another possibility: that a claim for "use and occupation" does not aim to make D perform a primary obligation, but aims to make $\mathrm{D}$ pay compensation for breach of a primary obligation (by imposing a secondary obligation on $\mathrm{D}$ to pay damages). In cases of this type, it is frequently unstated whether D's primary duty arose in contract (in which case such claims are essentially claims for breach of contract) or in tort (in which case they are essentially claims for trespass). However, if D had C's permission to occupy the property there cannot have been a trespass, and in such cases the claim must therefore be for breach of contract. This suggests that where D owes a contractual payment obligation which he fails to perform, there are two types of claim which $\mathrm{C}$ can bring against him: a claim for breach of contract and a claim in debt.

In recent times, certain judges and authors of leading textbooks have said that claims for "mesne profits" and claims for "compensation for use and occupation" are essentially one and the same. For example, in Dean and Chapter of Canterbury Cathedral $v$ Whitbread plc, ${ }^{18}$ the defendant held over at the determination of a lease, initially for the purpose of negotiating the terms of a new tenancy. His Honour Judge Cooke, sitting as a judge of the High Court, held that the defendant was a tenant at will without a fixed rent and that, in such cases, "an action for use and occupation may be maintained". ${ }^{19}$ According to the judge,

Where the holding over is consensual, as here, and not trespassory, the basis of the action is for a payment for use and occupation ... If the holding is trespassory, then the action is for "mesne profits", damages for trespass. Woodfall ... takes the view that the distinction is of no practical importance and none of the authorities cited to me suggest that there is any real difference in the measure of damage or sum payable or that the position in Woodfall is in any way to be doubted. It seems to me that I can obtain help from authorities on both types of claim. ${ }^{20}$

When he came to quantify the sum payable by the tenant at will, the judge therefore relied upon cases in which the courts had ordered a trespasser to pay "mesne profits" as well as cases where awards for "use and occupation" had been made.

Contrary to the view of the judge and the editors of Woodfall, however, we consider that there is a "real difference" between a claim in tort against a trespasser and a claim in contract or unjust enrichment against an occupier who had permission to occupy the property. In some situations, the amount of an award may be the same whether or not the claim is premised on D's occupation having been authorised. ${ }^{21}$ In other cases, however, this can make a difference to the award. For example, tort damages that are designed to compensate an owner

15 e.g. Wood v Newton (1746) 95 E.R. 538; Boot v Wilson (1807) 103 E.R. 360; Huffell v Armitstead (1835) 173 E.R. 25. For the history, see J.B. Ames, "Assumpsit for Use and Occupation" (1889) 2 Harvard L.R. 377.

${ }^{16}$ As noted in Harro Group Pty Ltd v Aspire Pty Ltd [2019] QSC 189, at [32].

${ }^{17}$ e.g. Bolton MBC v Torkington [2003] EWCA Civ 1634, [2004] Ch. 66; Derhalli v Derhalli [2019] EWHC 3286 (Ch).

18 (1996) 72 P. \& C.R. 9 (Ch).

${ }^{19}$ Ibid., 13.

${ }^{20}$ Ibid., 16.

${ }^{21}$ See e.g. Graves v Graves [2007] EWCA Civ 660, [2008] H.L.R. 10, at [47]. 
for a loss of rental income are usually assessed by reference to the market rental value of the property, but an award that is designed to enforce a contractual obligation to pay for the use of property is assessed by reference to the terms of the agreement. Nonetheless, changes in the law and pleading practice have made it harder to see that "claims for mesne profits" and "claims for use and occupation" might be separate categories of claim. ${ }^{22}$ One therefore needs to understand "claims for use and occupation" in order to understand "claims for mesne profits" as these are now frequently conceived. ${ }^{23}$

Unfortunately, the basis of "claims for use and occupation" is not well understood. Many judges and scholars have said that these are founded on an "implied contract" under which D agreed to pay a reasonable sum in exchange for the use and occupation of C's land. However, they have not drawn a clear distinction between "contracts implied in fact", i.e. legally binding agreements that the parties intended to enter, and "contracts implied in law", i.e. obligations deemed to have arisen not because the parties intended this but for some other reason. For example, the editors of Woodfall say that

In modern law, an award of compensation for use and occupation is a restitutionary remedy, based upon quasi-contract. It arises where a person has been given permission to occupy the land of another without any binding terms having been agreed about payment. In such circumstances the law will imply a promise on the part of the occupier to pay a reasonable sum for his use and occupation of the land. At common law a claim could also be brought where there was an actual promise to pay either a fixed amount or a reasonable sum. ${ }^{24}$

Similarly, the editors of Hill and Redman's Law of Landlord and Tenant assert that:

Where a person has been in occupation of land without an agreement fixing an amount of rent the landlord may bring an action against the occupier for use and occupation to recover a sum in reasonable satisfaction for the lands held or occupied... [T] he action lies at common law and is quasi-contractual, based on the breach by the occupier of an implied term to pay a fair and reasonable rent for the enjoyment of the land occupied. ${ }^{25}$

The editors of Megarry \& Wade also maintain that the right to recover a reasonable sum for the use and occupation of land is "based upon implied contract". ${ }^{26}$

There are historical precedents for this view. In Beverley v Lincoln Gas Light and Coke Co., for instance, Patteson J. said that "where a benefit has been enjoyed, such as the occupation

${ }^{22}$ Another reason for the blurring of conceptual boundaries which has taken place is the practice which has emerged of describing "mesne profits" as "damages for use and occupation": e.g. Rogers v Lambeth LBC (2000) 32 H.L.R. 361 (C.A.) 371; Mohammadiv Anston Investments Ltd [2003] EWCA Civ 981, [2004] H.L.R. 8, at [37]; Cook v Thomas [2010] EWCA Civ 227, at [108]; J. Furber and J.R. Moss (eds), Hill and Redman's Law of Landlord and Tenant (loose-leaf edn, London, 2020), para. 5184.

${ }^{23}$ A further problem created by the muddle is that it can make the wording of settlement agreements difficult to interpret, as in e.g. Thorne v Courtier [2011] EWCA Civ 460.

${ }^{24}$ The Hon. Lord Justice Lewison et al (eds), Woodfall, Landlord and Tenant (loose-leaf edn, London, 2020 release) vol. 1, para. 10.001.

${ }^{25}$ Hill and Redman para. 1830.

${ }^{26}$ E. Cooke, S. Bridge and M. Dixon (eds), Megarry \& Wade: The Law of Real Property (9th edn, London, 2019) para. 18-094. 
of [the claimants'] lands, by their permission, the law will imply a promise to make them compensation." 27 Similarly, in Gibson v Kirk Lord Denman C.J. said that

the implied contract is raised by law from the fact that land belonging to the plaintiff has been occupied by the plaintiff's permission; the obligation is coextensive with, and measured by, the enjoyment; as soon as the occupation ceases, the implied contract ceases. $^{28}$

The "implied contract" rule was also applied in Howard $v$ Shaw. ${ }^{29}$ The defendant agreed to buy certain land from the claimant for £1200. The defendant was let into possession of the premises in September 1827 under the contract of sale. The sale was not completed, and the defendant remained in possession without paying any rent until October 1839. The claimant brought an action in assumpsit for use and occupation. The defendant contended that the action was not maintainable, because the relation of landlord and tenant had never existed between the parties. The Court of Exchequer held that the defendant was required to pay a reasonable sum to the claimant. Lord Abinger C.J. said:

what is the relation of the parties when the contract of sale has gone off? The defendant remains in possession with the consent of the landlord, but without any title to or contract to purchase the land itself. Under those circumstances, he is a tenant at will; and if the occupation is beneficial to him, that is sufficient to imply a contract to pay a reasonable sum by way of compensation for such occupation. ${ }^{30}$

As a number of commentators have pointed out, ${ }^{31}$ however, the courts' use of "implied contract" in such cases obscures the distinction between a genuine, albeit implicit, contract and a fictitious contract. If it is said of every case where D has occupied and used C's land with C's consent that the law "implies a contract" to pay a reasonable sum, this obscures the fact that in some cases, D's liability arises under a legally binding agreement, but that in others it does not. For example, consider Hellier $v$ Sillcox. ${ }^{32}$ Title to a cottage had descended to the claimant on the death of his father, subject to the widow's right to occupy the cottage during her life. The defendant occupied the cottage with the widow and remained in possession after her death, without paying any rent to the widow or the claimant. The claimant brought an action in assumpsit for use and occupation, and the court found in his favour. Lord Campbell C.J. said that the question was "whether an action for use and occupation would lie" and he concluded that it would, because "the defendant occupied by the [claimant]'s permission." 33 However, there is nothing in the report to suggest that there was a genuine contract between the parties, and this was later recognised by Pollock C.B. in Churchward v Ford, where he said that

27 (1837) 112 E.R. 318, 322.

28 (1841) 113 E.R. 1357, 1359.

${ }^{29}$ (1841) 151 E.R. 973. See also Dean of Rochester v Pierce (1808) 170 E.R. 1023; Mayor of Stafford v Till (1827) 130 E.R. 697; Mayor of Thetford $v$ Tyler (1845) 115 E.R. 810, 812.

30 (1841) 151 E.R. 973, 974-5.

31 This point has been made by many legal scholars. Two examples are D. Ibbetson, "Implied Contracts and Restitution: History in the High Court of Australia" (1988) 8 O.J.L.S. 312; J.H. Baker, "The Use of Assumpsit for Restitutionary Money Claims 1600-1800" in J.H. Baker, Collected Papers on English Legal History (Cambridge, 2013) vol III, 1312.

32 (1850) 19 L.J. Q.B. 295.

${ }^{33}$ Ibid. 296. 
where nothing appears except that one person is entitled to land which another has occupied and enjoyed, an action for use and occupation may be maintained, because a contract may be implied. That explains the decision in the case of Hellier $v$ Sillcox. ${ }^{34}$

We have already quoted statements in the main practitioner texts on landlord and tenant that even if the parties have no genuine contract, an authorised occupier's obligation to pay for the "use and occupation" of land arises under a contract "implied by law" and is "quasicontractual" in nature. It is time that the editors removed such statements from their books. They rest on an "implied contract theory" of "quasi-contractual" claims that was definitively rejected in favour of an unjust enrichment analysis 25 years ago, in Westdeutsche Landesbank Girozentrale v Islington L.B.C. ${ }^{35}$ Other cases to the same effect have followed and collectively these place it beyond doubt that the implied contract theory which was once thought to explain restitutionary liability in cases where the parties had no actual contract is "a ghost of the past". ${ }^{36}$ It is now simply incorrect to say that "compensation for use and occupation is a restitutionary remedy, based upon quasi-contract." ${ }^{37}$ Only once this is recognised, and the indiscriminate use of the notion of an "implied contract" rejected, does it become possible to draw a clear line between claims in respect of the occupation of land that are based on contract and claims that are based on unjust enrichment.

\section{CLAIMS BASED ON THE TORT OF TRESPASS}

As we have said, mesne profits were originally conceived as a type of compensatory damages for trespass to land. It was once usual, in cases where $\mathrm{C}$ was not in possession of the land when D's wrongful occupation began, for $\mathrm{C}$ to bring an action for ejectment to recover possession as a preliminary step, and then to bring a trespass action to recover mesne profits. $\mathrm{C}$ had to proceed in this way owing to a rule that "a possession in fact in the plaintiff ... is necessary to support an action for a trespass". ${ }^{38}$ If, for example, a landlord became entitled to possession of land following the expiry of the lease, he could not recover damages for trespass from the former tenant for wrongfully holding over, or against a third party who intruded onto the land, unless and until he had re-entered the land. ${ }^{39}$ This is why "the claim for mesne profits was always brought after re-entry and usually after a successful writ of ejectment.",40

${ }^{34}$ (1857) 157 E.R. $184,185$.

35 [1996] A.C. 669, 710 (H.L.). See too Pavey \& Matthews Pty Ltd. v Paul (1987) 162 C.L.R. 221, 227 and 256-7 (H.C.A); Sempra Metals Ltd. v IRC [2007] UKHL 34, [2008] 1 A.C. 561, at [112]-[113]; Benedetti v Sawiris [2013] UKSC 50, [2014] A.C. 938, at [148].

${ }^{36}$ Cleveland Bridge U.K. Ltd. v Multiplex Constructions (U.K.) Ltd. [2010] EWCA Civ 139, at [121]. See too Haugesund Kommune v Depfa ACS Bank [2010] EWCA Civ 579, [2012] Q.B. 549, at [87]; Lone v Hounslow LBC [2019] EWCA Civ 2206, [2020] 1 W.L.R. 952, at [47]. For the history, see D. Ibbetson, A Historical Introduction to the Law of Obligations (Oxford, 2001) 276-81.

${ }^{37}$ Woodfall, Landlord and Tenant, para. 10.001.

${ }^{38}$ Wilkinson v Kirby (1854) 139 E.R. 492, 497 (Jervis C.J.).

${ }^{39}$ Butcher v Butcher (1827) 108 E.R. 772; Hey v Moorhouse (1839) 133 E.R. 20; Jones $v$ Chapman (1849) 154 E.R. 717, 724 (Maule J.).

${ }^{40}$ Hampton v BHP Billiton Minerals Pty. Ltd. [2012] WASC 285, at [310] (Edelman J.). The main remedy awarded to a successful plaintiff in an action for ejectment was a writ of possession (ordering the sheriff to remove the defendant and restore the plaintiff to the disputed land). Substantial damages could not be recovered where the action was brought by a freeholder because the action was founded (prior to reform by the Common Law Procedure 
A problem was created by this "actual possession" rule, however, because it was held to mean that in cases of the kind we have described the landlord could not recover damages for the period when he was out of possession - and this was, of course, exactly the time when the trespass occurred. To overcome this, a legal fiction was introduced, known as "trespass by relation". The fiction was - and still is - that if a person who has a right to possession enters onto the land he is deemed to have been in possession from the moment when the right to possession accrued. ${ }^{41}$ His entry onto the land "relates back" to the time at which the right arose. $^{42}$ This was described by Lord Brougham L.C. in Carnegy v Scott:

[As] soon as a person recovers possession of the land [in an action of ejectment], that is to say, as soon as he shews that he, and not the person in possession before, is entitled to hold that property, he recovers all the rents and profits from the tenant as far back as the statute of limitations allows him to go in quest of his right. No question was ever allowed to be raised as to the footing on which that possession had been holden. ${ }^{43}$

The modern law concerning trespass to land has not wholly abandoned the requirement of actual possession. ${ }^{44}$ But the requirement has been significantly qualified, and not only by the doctrine of relation. A second qualification is that a person who has a right to possession in respect of certain land will be deemed to be in actual possession of it, in the absence of evidence that another person is in possession. ${ }^{45} \mathrm{~A}$ third is that a person who has a reversionary interest in land can recover damages for trespass from a person who has caused permanent damage to the land. ${ }^{46}$ A fourth is that mesne profits may be recovered in an action for possession. This rule, which saves claimants from having to bring two actions, was first introduced in 1820 and originally applied only where an action of ejectment was brought by a landlord. ${ }^{47}$ Nowadays, $\mathrm{C}$ can recover mesne profits in an action for possession, whether or not he is a landlord. ${ }^{48}$

Act 1852) on a fictitious lease held by a nominal plaintiff: F.W. Maitland, The Forms of Actions at Common Law: A Course of Lectures (Cambridge, 1936) Lecture V. Damages awarded in ejectment actions were therefore nominal: W. Woodfall, The Law of Landlord and Tenant (4th edn, London, 1814) 418. The fictional pleadings in ejectment were not carried over into associated actions of trespass, however, and the damages awarded to successful plaintiffs in trespass actions corresponded to the loss suffered by the true plaintiff: Goodtitle v Tombs (1770) 95 E.R. 965, 966-67.

${ }^{41}$ Barnett $v$ Earl of Guildford (1855) 156 E.R. 728; Radcliffe v Anderson (1860) 120 E.R. 715; Ocean Accident and Guarantee Corp. v Ilford Gas Co. [1905] 2 K.B. 493 (C.A.).

${ }^{42}$ Barnett v Earl of Guildford (1855) 156 E.R. 728, 733 (Parke B.); Ocean Accident and Guarantee Corp. v Ilford Gas. Co. [1905] 2 K.B. 493, 497-98 (Collins M.R.); Minister of State for the Interior v R.T. Co. Pty. Ltd. [1962] HCA 29, (1962) 107 C.L.R. 1, 5-6 (Taylor J.).

${ }^{43}$ (1830) 5 E.R. 843, 844. See too Goodtitle v Tombs (1770) 95 E.R. 965, 966-67.

${ }^{44}$ Cf. Hampton v BHP Billiton Minerals Pty. Ltd. [2012] WASC 285, at [270]-[318] (Edelman J).

${ }^{45}$ Bocardo S.A. v Star Energy U.K. Onshore Ltd. [2010] UKSC 35, [2011] 1 A.C. 380, at [29][31] (Lord Hope).

${ }^{46}$ Mayfair Property Co. v Johnston [1894] 1 Ch. 508 (Ch).

${ }^{47}$ Recovery of Possession by Landlords Act 1820 (1 Geo. 4, c. 87), s. 2; Common Law Procedure Act 1852 (15 \& 16 Vict., c. 76), s. 214.

${ }^{48}$ Dunlop v Macedo (1891) 8 T.L.R. 43 (Q.B.); Southport Tramways Co. v Gandy [1897] 2 Q.B. 66 (C.A.); Portland Managements Ltd v Harte [1977] Q.B. 306 (C.A.). See "Mesne Profits" (1964) 108 Sol. J. 570. Cf. C.P.R. rule 7.3: "A claimant may use a single claim form to start all claims which can be conveniently disposed of in the same proceedings." 
Alternatively, $\mathrm{C}$ can bring an action for possession and then a second action for mesne profits, in which case the second action will not be struck out for res judicata, because

each day ... of [D's] unlawful occupation ... as a trespasser constitutes a fresh, separate cause of action giving rise to a claim for mesne profits for that occupation for that period ... [whereas] a claim for possession ... [only involves the claimant] in having to show that it had a good cause of action as at the date of the order for possession. ${ }^{49}$

These qualifications to the actual possession rule prevent it from applying in almost every case. The time has come to recognise that the rule has been so hollowed out by exceptions that it may as well be abolished.

Note, finally, that (subject to the rules on limitation) the period for which a trespasser is liable for mesne profits generally starts with the commencement of the trespass and ends when the trespasser surrenders possession. ${ }^{50}$ The latter rule was applied in Southport Tramways $v$ Gandy $C o,{ }^{51}$ where the claimants brought an action for possession and mesne profits against a former tenant. Kennedy $\mathbf{J}$ awarded "mesne profits to be calculated up to the date of the plaintiffs obtaining possession." 52 The defendant appealed, contending that mesne profits could be awarded only up to the time of the possession order, and that a second action was needed to recover mesne profits in respect of the period following the order. But the Court of Appeal upheld the judge's decision, Rigby LJ stating that he had been "quite right in making an order giving mesne profits till the time when the plaintiffs obtain possession. It would have been wrong to drive the plaintiffs to bring a second action." 53

\section{CLAIMS BASED ON CONTRACT}

There are many cases in which the courts have awarded "compensation for use and occupation" and the basis of the award was contractual, i.e. there was a genuine contract between the parties and the (express or implied) terms of this contract provided that the defendant was required either to pay a reasonable sum or to pay a specified fixed amount for occupying the land. ${ }^{54}$ Such a contract is often entered in two situations: first, where a lease expires, and the tenant holds over with the consent of the landlord, and, second, where two parties are negotiating the

${ }^{49}$ Farrar v Leongreen Ltd [2017] EWCA Civ 2211, [2018] 1 P. \& C.R. 17, at [15].

${ }^{50}$ When a lease is forfeited after quarterly rent has been paid in advance, and the tenant wrongfully remains in possession into the next quarter, the modern rule of practice is to allow the landlord to keep the advance payment and claim mesne profits only for the period in respect of which he has not already been paid: T. Boncey and J. Tipler, "Implied Terms: From 'Characteristically Inspired Discussion' to Authoritative Guidance" (2016) 20 Landlord \& Tenant Review 4, 10-11, noting Canas Property Co. Ltd. v KL Television Services Ltd. [1970] 2 Q.B. 433 (C.A.) and Capital \& City Holdings Ltd. v Dean Warburg Ltd. (1989) 58 P \& CR 346 , but querying whether this rule of practice is well-founded in principle and whether these cases are consistent with obiter dicta from Lord Neuberger in Marks \& Spencer P.L.C. v BNP Paribas Securities Services Trust Co. (Jersey) Ltd .[2015] UKSC 72, [2016] A.C. 742, at [47]. ${ }^{51}$ [1897] 2 Q.B. 66 (C.A.). See too Jones v Merton L.B.C. [2008] EWCA Civ 660, [2009] 1 W.L.R. 1269 (C.A.).

${ }^{52}$ Ibid., 67.

${ }^{53}$ Ibid., 70.

54 The fact that an award of damages for "use or occupation" may be based on a genuine contract between the parties was recognised by Lord Atkinson in Attorney-General $v$ De Keyser's Royal Hotel [1920] A.C. 508, 533 (H.L.). 
terms of a lease and the intended grantee is permitted to occupy the land before negotiations are concluded. In Uzun $v$ Ramadan,${ }^{55}$ for example, the claimant entered negotiations with the defendant for the grant of a fixed term lease of a restaurant. Before these were concluded, the claimant took possession and agreed to pay $£ 200$ per week in rent. However, negotiations for the grant of a fixed term tenancy broke down, the claimant failed to pay $£ 200$ per week, and the defendant evicted him. Sir Frank Douglas Q.C. held that the claimant occupied the restaurant as a tenant at will and awarded the defendant " $£ 2,640$ for use and occupation". ${ }^{56}$ The tenancy at will was not granted by a written agreement, ${ }^{57}$ but it was clear from the parties' conduct and oral communications that they had entered a legally binding agreement, one term of which was that the claimant should pay $£ 200$ per week.

Importantly, the fact that the parties were negotiating for, although they failed to agree on, the grant of a fixed term tenancy was not inconsistent with the existence of a preliminary contract under which the defendant was granted a tenancy at will at a rent. ${ }^{58}$ This proposition is supported by the Court of Appeal's reasoning in Barclays Wealth Trustees (Jersey) Ltd. $v$ Erimus Housing Ltd ${ }^{59}$ The claimant granted the defendant a lease of certain business premises for five years. Before the term expired, the parties entered negotiations for the grant of a new fixed term tenancy. No agreement was reached about that, but the defendant remained in occupation with the consent of the claimant and made payments that were equal to the rental payments under the original lease. A dispute arose as to whether, following expiry of the original term, the defendant had occupied as a tenant at will or as a yearly tenant. The Court of Appeal held that the defendant had been a tenant at will. Patten L.J. explained that "the parties' contractual intentions fall to be determined by looking objectively at all relevant circumstances." ${ }^{\prime 60}$ Given that the parties were negotiating for the grant of a new fixed term tenancy, "the obvious and almost overwhelming inference [was] that the parties did not intend to enter into any intermediate contractual arrangement inconsistent with remaining parties to ongoing negotiations." 61 This led to the conclusion that the defendant occupied the premises, not as a yearly tenant, but as a tenant at will. ${ }^{62}$ The contention that the parties had agreed that the defendant would occupy under a tenancy at will, which could have been determined by either party at any time, was compatible with the fact that the parties were negotiating the grant of a fixed term tenancy. Indeed, as Patten L.J. explained, such an "interim arrangement suited both parties because it gave [the defendant] continued possession of the premises and [the claimant] a rent which was probably equal to or in excess of the market rent."63

There is one group of cases in which the occupier's liability might appear to have been contractual, but where the courts have held that there was, in fact, no contract. These concern a class of occupiers known as "tolerated trespassers." As Lord Neuberger has observed, this

\footnotetext{
${ }^{55}$ [1986] 2 E.G.L.R. 255 (Q.B.). See too Eleftheriou v Costi [2013] EWHC 2168 (Ch), at [39]. ${ }^{56}$ Ibid., 258.

${ }^{57}$ Contrast: Manfield \& Sons v Botchin [1970] 2 Q.B. 612 (Q.B.); Hagee (London) Ltd. v A.B. Erikson and Larson [1976] Q.B. 209 (C.A.).

${ }^{58}$ Cf. Turner v York Motors Pty. Ltd. (1951) 85 C.L.R. 55 (H.C.A.) 65. For a general discussion of cases in which parties failed to conclude an intended contract but were nonetheless bound by a collateral or preliminary contract, see H. Beale (ed.), Chitty on Contracts (33rd edn, London, 2018), paras. 2-209, 2-210, 2-217, 2-219.

59 [2014] EWCA Civ 303, [2014] 2 P. \& C.R. 4.

${ }^{60}$ Ibid., at [23].

${ }^{61}$ Ibid., at [23].

${ }^{62}$ Ibid., at [23]. This part of Patten L.J.'s judgment embraces the influential reasoning of Nicholls L.J. in Javad v Aqil [1991] 1 W.L.R. 1007 (C.A.).

${ }^{63}$ Ibid., at [16].
} 
status is "conceptually peculiar, even oxymoronic". ${ }^{64}$ It is, therefore, unsurprising that the rights of "tolerated trespassers" have been extensively discussed. ${ }^{65}$ However, far less attention has been paid to the nature and source of the liability owed by tolerated trespassers to pay "mesne profits" in respect of their occupation and so we shall now examine this.

"Tolerated trespassers" were a creation of the Housing Act 1985, before the law was changed by the Housing Regeneration Act 2008 and associated legislation. ${ }^{66}$ Part IV of the 1985 Act contained (and still contains) provisions governing "secure tenancies". A tenancy under which a dwelling-house is let as a separate dwelling is a secure tenancy if the landlord is a local authority (or one of the other bodies listed in section 80(1)) and the tenant is an individual and occupies the dwelling-house as his only or principal home.

By virtue of section 82, a secure tenancy cannot be brought to an end except by obtaining an order of a court, including an order for possession of the house. Section 82(2), as enacted, provided that "[w]here the landlord obtains an order for the possession of the dwelling-house, the tenancy ends on the date on which the tenant is to give up possession in pursuance of the order." This was authoritatively interpreted as meaning that a secure tenancy ends, not when the order for possession is executed, but upon the date on which the order requires the defendant to give up possession or, where the order is suspended on terms, when the tenant ceases to comply with the terms. ${ }^{67}$

Section 84 concerns the grounds on which an order for possession may be made. A court may make a possession order on the basis of non-payment of rent, and some other grounds, only if the court is satisfied that it is reasonable to make the order. In such cases, the court, by virtue of section 85 , may, upon making the order or at any time before the execution of the order, stay or suspend the execution of the order, or postpone the date of possession for so long as it thinks fit.

The courts then held that the power to postpone the date for possession could be exercised after the date for possession specified in the order had passed and the tenancy had been terminated by virtue of section $82(2) .{ }^{68}$ Hence, the court had the power, until the possession order was executed, to vary the date for the giving up of possession and thereby to revive the old tenancy. ${ }^{69}$ Where the tenancy was revived, this happened retrospectively, i.e. the law regarded the tenancy as having existed all along.

${ }^{64}$ Knowsley Housing Trust $v$ White [2008] UKHL 70, [2009] 1 A.C. 636, at [79]. See also: Austin v Southwark L.B.C. [2010] UKSC 28, [2011] 1 A.C. 355, at [45] (Baroness Hale).

65 e.g. S. Bright, "The Concept of the Tolerated Trespasser: An Analysis" (2003) 119 L.Q.R. 495; I. Loveland, "Tolerated Trespass: A Very Peculiar Legal Creature" (2007) 123 L.Q.R. 455.

${ }^{66}$ Section 299 of, and Part 1 of Schedule 11 to, the 2008 Act, which came into force on 20 May 2009 , prevented the creation of further "tolerated trespassers" by providing that, where a landlord obtains a possession order against a secure tenant, the tenancy continues until the landlord recovers possession. The effect of Part 2 of Schedule 11, and certain secondary legislation made thereunder, was to convert existing "tolerated trespassers" into tenants.

${ }^{67}$ Thompson v Elmbridge B.C. [1987] 1 W.L.R. 1425 (C.A.); Burrows v Brent L.B.C. [1996] 1 W.L.R. 1448 (H.L.); Harlow D.C. v Hall [2006] EWCA Civ 156, [2006] 1 W.L.R. 2116; Knowsley Housing Trust v White [2009] 1 A.C. 636; Austin v Southwark L.B.C. [2011] 1 A.C. 355.

${ }^{68}$ Greenwich L.B.C. v Regan (1996) 28 H.L.R. 469 (C.A.); Burrows v Brent L.B.C. [1996] 1 W.L.R. 1448.

${ }^{69}$ Greenwich L.B.C. v Regan (1996) 28 H.L.R. 469 Burrows v Brent L.B.C. [1996] 1 W.L.R. 1448. The court also has a power, by virtue of s. $85(4)$, to discharge or rescind an order for 
A "tolerated trespasser" was a person who remained in occupation after his secure tenancy had ceased to exist by virtue of a possession order, but against whom the order had not been executed. ${ }^{70}$ It is important to distinguish three varieties of "tolerated trespasser". ${ }^{71}$ First, there was the occupier who had entered into an agreement with the former landlord whereby the former landlord agreed not to execute the possession order so long as the occupier met certain conditions (typically, the timely payment of certain monetary sums). ${ }^{72}$ Second, there was the occupier who entered into no such agreement, but who remained in occupation because the former landlord simply failed to take steps to enforce the possession order. ${ }^{73}$ Third, there was the occupier who was occupying the land where the court had stayed or suspended the execution of the order (usually subject to certain conditions). ${ }^{74}$

The third kind of "tolerated trespasser" may or may not have been under a duty to make payments in respect of his occupation, depending on the terms of the court order. Section 85(3), as originally enacted, provided (inter alia) that, if the court stayed or suspended the execution of the order, the court "shall impose conditions with respect to ... payments in respect of occupation after the termination of the tenancy (mesne profits), unless it considers that to do so would cause exceptional hardship to the tenant or would otherwise be unreasonable".

So far as the first and second kinds of "tolerated trespasser" were concerned, it is clear that they could be ordered to pay "mesne profits" to the owner in respect of their occupation. ${ }^{75}$ In Jones v Merton L.B.C. ${ }^{76}$ for example, the defendant occupied a flat under a secure tenancy within Part IV of the Housing Act 1985. He occupied the flat as a "tolerated trespasser" from 11 February 2005 and ceased to occupy it in November 2005. The authority contended that the period in respect of which the defendant was liable to pay "mesne profits" ended in September 2006, when the defendant notified the authority that he was no longer in occupation. This was accepted by the County Court judge but rejected by the Court of Appeal. Wilson L.J. accepted that a "tolerated trespasser", like an ordinary trespasser, "ceases to be liable for mesne profits when he gives up possession, irrespective of notice."77

What was the basis of the liability of a "tolerated trespasser" to pay "mesne profits"? The use of the term "trespasser" might lead one to conclude that the liability was wrongs-based. The problem with this idea, however, is that the former landlord usually consented, at least for a time, to the continuation of the occupation; and, as Jones illustrates, the occupier was liable to pay "mesne profits" in respect of the entire period of occupation (and not merely the period, if any, for which he had occupied without the consent of his former landlord). The fact that the occupation of a tolerated trespasser was usually consensual, at least for a time, is illustrated by cases in which the former landlord and the occupier reached an express agreement to the effect that the possession order would not be executed for as long as certain payments were made. For example, in Burrows v Brent L.B.C., ${ }^{78}$ the local authority obtained a possession order against Burrows, requiring her to give up possession on a certain date. Her secure tenancy

possession, and the effect of discharging or rescinding a possession order was to revive the tenancy.

${ }^{70}$ Burrows v Brent L.B.C. [1996] 1 W.L.R. 1448, 1455 (Lord Browne-Wilkinson).

${ }^{71}$ Jones v Merton L.B.C. [2009] 1 W.L.R. 1269, at [8] (Wilson LJ).

${ }^{72}$ See e.g. Burrows v Brent L.B.C. [1996] 1 W.L.R. 1448.

${ }^{73}$ See e.g. Jones $v$ Merton L.B.C. [2009] 1 W.L.R. 1269.

${ }^{74}$ See e.g. Harlow D.C. v Hall [2006] 1 W.L.R. 2116.

75 Pemberton v Southwark L.B.C. [2000] 1 W.L.R. 1672, 1681 (Roch L.J.) and 1683-84

(Clarke L.J.); Jones v Merton L.B.C. [2009] 1 W.L.R. 1269.

${ }^{76}$ [2009] 1 W.L.R. 1269.

77 Ibid., at [25].

${ }^{78}$ [1996] 1 W.L.R. 1448. 
ended on that date, but she remained in possession by an agreement with the local authority under which it agreed not to execute the order and she agreed to pay a weekly "rent charge" and a regular sum in reduction of the arrears. The local authority allowed her to remain in occupation on these terms. In other words, from the moment the agreement was concluded, Burrows occupied the land with the authority's consent. Her initial occupation was, therefore, not wrongful. ${ }^{79}$

If the parties entered no agreement, but the former landlord refrained from executing the order, then once again the occupier's continuing occupation was usually consensual. As Baroness Hale explained in Austin v Southwark L.B.C., "[t]hese were people whom the authority wanted to have there, provided they could be persuaded to pay most, if not all, of their rent. ${ }^{80}$ In Marshall v Bradford M.D.C. ${ }^{81}$ for example, the local authority won an order for possession that was suspended so long as the tenants (the claimant and her husband) paid the rent and made certain payments in reduction of the rent arrears. The terms of the order were breached, but the claimant remained in possession for several years and eventually paid the arrears in full. There was no express agreement between the authority and the claimant, but Chadwick L.J. considered that there had come a time when "the District Council must be taken to have accepted that [the claimant] could remain in occupation of the premises for so long as the arrangements for regular payments ... continued in force." $\$ 2$

If the occupier's liability was not wrongs-based, then what was its basis? It is tempting to say that it was contractual: if the occupier and the former landlord agreed that the possession order was not to be executed for so long as the occupier paid for her occupation, an obvious inference might be that this agreement created a new tenancy or a contractual licence by virtue of which the occupier would be required to pay the landlord/licensor in respect of the occupation. However, the House of Lords specifically held in Burrows that such an agreement did not, without more, create a new tenancy or licence, and hence the occupier's liability to pay for her occupation could not have derived from, or have been based upon, the terms of a tenancy or contractual licence. ${ }^{83}$ Lord Browne-Wilkinson, giving the leading speech, gave two reasons for taking this view. First, the parties "plainly did not intend to create a new tenancy or licence" ${ }^{84}$ It is unclear what his Lordship had in mind here, ${ }^{85}$ but a plausible interpretation is that he thought that the parties did not wish the agreement to be legally binding, i.e. with respect to the new agreement, they did not intend to create legal relations. ${ }^{86}$ Second, if the agreement not to execute the possession order created a new tenancy or licence, then the occupier would once again become a "secure tenant" and the landlord would be taken back to square one: it would need to obtain a new possession order. Lord Browne-Wilkinson was concerned that, if this were the position, the practical result would be

79 The authority's consent was subsequently withdrawn. Burrows failed to comply with the agreement and the authority decided to issue a warrant for possession.

${ }^{80}$ [2011] 1 A.C. 355 , at [45].

81 [2001] EWCA Civ 594, [2002] H.L.R. 22. The Court of Appeal's judgment was partially overruled in Knowsley Housing Trust $v$ White [2009] 1 A.C. 636, but this has no bearing on the point discussed in the text.

${ }^{82}$ Ibid., at [26].

${ }^{83}$ Burrows v Brent L.B.C. [1996] 1 W.L.R. 1448.

${ }^{84}$ Ibid., 1454.

${ }^{85}$ S. Bright, "Tolerated Trespass or a New Tenancy?" (2006) 122 LQR 48, 51-52.

${ }^{86}$ Lambeth L.B.C. v O'Kane [2005] EWCA Civ 1010, [2006] H.L.R. 2, at [60]; Bright, "The Concept of the Tolerated Trespasser", 508; Chitty on Contracts, para. 2-197. 
either that the local authority will be reluctant to make reasonable and humane concessions by agreement or in every case will have to make an application to the court to vary the existing order so as to ensure that the old tenancy is not brought to an end. ${ }^{87}$

His Lordship found it "impossible to believe that Parliament intended to produce such an unreasonable regime, penalising sensible agreements out of court and requiring repeated applications to an already overstretched court system." 88

If, as the House of Lords held in Burrows, there was no new tenancy or contractual agreement between the former landlord and the occupier, then her liability to make payments in respect of her occupation cannot have been based on the terms of a tenancy or a contractual licence. Hence the law of contract can provide us with no better explanation for her liability than the law of tort. ${ }^{89}$ So we must look elsewhere - to the law of unjust enrichment.

\section{CLAIMS BASED ON UNJUST ENRICHMENT}

In Morris $v$ Tarrant,${ }^{90}$ Lane $\mathrm{J}$ rejected the possibility that a claim in unjust enrichment might lie to recover the value of occupying and using land, at least where there had been a trespass. The parties were a married couple who separated, the wife leaving the marital home although it belonged to her, and the husband remaining. The marriage was dissolved by decree absolute, and the wife regained possession. She sought an order that the husband should pay for his occupation between her departure and re-entry. Her case was put on three separate bases.

First, she claimed that the husband had been a trespasser so that "mesne profits" (meaning compensatory damages) were payable. This was partially successful: Lane J held that the husband had not been a trespasser between the wife's departure and the granting of the decree but had been a trespasser between the granting of the decree and the wife's re-entry. The judge therefore awarded mesne profits for the later, although not for the earlier, period.

Second, the wife argued that there had been a legally binding agreement that the husband would pay for his occupation during the earlier period, if not under a lease then under a license. Lane $\mathrm{J}$ rejected this, finding that no such agreement had existed.

Third, the wife argued that with respect to the later period she also had a claim

on the basis of unjust enrichment. Where A has received the property of B and has thereby enriched himself at the expense of $\mathrm{B}$, it is just and equitable that there should be restitution to $\mathrm{B}$ in circumstances where it would be unjust for $\mathrm{A}$ to retain the benefit of that enrichment. The doctrine does not depend on contract or tort but on the equitable principle of restitution. On the facts, the defendant has been unjustly enriched by his occupation of the plaintiff's premises which he used both as a residence and as his business premises in running the farm. The period of enrichment should be computed from the date of the decree absolute. ${ }^{91}$

Lane $\mathrm{J}$ rejected this, too, holding that the "doctrine of unjust enrichment simpliciter" was not a cause of action on which a claim could be founded: the claimant had to bring herself within the

${ }^{87}$ [1996] 1 W.L.R. 1448, 1454.

${ }^{88}$ Ibid.

${ }^{89}$ The occupier's liability to make payments in respect of her occupation cannot be based on the doctrine of promissory estoppel either, because this doctrine does not create new rights; it merely precludes the enforcement of existing rights: Combe $v$ Combe [1951] 2 K.B. 215 (C.A.). 90 [1971] 2 Q.B. 143 (Q.B.).

${ }^{91}$ Ibid., 148 (arguendo). 
scope of an existing precedent, and she could not do this because the law of unjust enrichment derived from cases that concerned money claims and it would be "undesirable and would lead to uncertainty" if the principles disclosed by these cases were "arbitrarily extended" to a case that was concerned not with money but with the use and occupation of land, "at any rate where an alternative remedy was available" in tort. ${ }^{92}$

Since Lane $\mathrm{J}$ had decided to award tort damages for the later period, her findings about the unjust enrichment claim were brief. They were also made at a time that predated the modern recognition that unjust enrichment is a category of the English law of obligations, emergence of an analytical structure by reference to which claims should be pleaded, generalisation of the principles that justify recovery in such cases, and refinement of these to allow for variations required by different sets of facts. These changes have occurred over the last 30 years and they

are ongoing. ${ }^{93}$ It seems most likely, however, that a court would now regard some parts of Lane J's analysis as incorrect and other parts as correct.

Contrary to the judge's comments, a modern court would not think it wrong to analogise between money cases and non-money cases and to hold that a reason for restitution of the value of money can also be a reason for restitution of the value of other types of benefit, including the opportunity to occupy and use land. ${ }^{94}$ Furthermore, the judge's view that a claim in unjust enrichment should not be permitted where the facts disclose another cause of action such as the tort of trespass would now be thought insufficiently nuanced. Nowadays concurrent claims in tort and unjust enrichment are thought to be possible in some situations, ${ }^{95}$ although there is a consensus that a claim in unjust enrichment is almost always impermissible in cases where the parties' relationship is governed by a contract. ${ }^{96}$

Consistently with Lane J's observations, however, there is also a modern consensus that "unjust enrichment" is no more a cause of action than "tort". Just as a tort claimant must plead the ingredients of e.g. assault, battery, or conversion, rather than simply pleading "tort", so a claimant cannot simply plead "unjust enrichment" and must identify the ingredients of his claim with greater specificity. ${ }^{97} \mathrm{He}$ must plead that the defendant was enriched, that the

${ }^{92}$ Ibid., 162.

${ }^{93}$ Definitive recognition of unjust enrichment as a discrete source of rights and obligations in English law dates from Lipkin Gorman v Karpnale Ltd [1991] 2 A.C. 548, 578 (H.L.).

${ }^{94}$ Cf. Benedetti v Sawiris [2013] UKSC 50, [2014] A.C. 938, at [175] (claims grounded on failure of consideration can lie to recover the value of services); Harro Group Pty Ltd $v$ Aspire Pty Ltd [2019] QSC 189, at [30]-[33] (claims grounded on failure of consideration can lie to recover the value of using and occupying land, although not if the parties have a contract that would thereby be subverted).

${ }^{95}$ Universe Tankships Inc. of Monrovia v International Transport Workers Federation [1983] 1 A.C. 366, 385 (H.L.); Deutsche Morgan Grenfell Group plc v IRC [2006] UKHL 49, [2007] 1 A.C. 558, at [51]; Sempra Metals Ltd v IRC [2007] UKHL 34, [2008] 1 A.C. 561, at [70]. 96 The leading case is Macdonald Dickens \& Macklin (a firm) v Costello [2011] EWCA Civ 930, [2012] Q.B. 244. For general discussion, see C. Mitchell, P. Mitchell and S. Watterson, Goff and Jones: The Law of Unjust Enrichment (9th edn, London, 2016), paras. $3.10 \mathrm{ff}$.

${ }^{97}$ Lampson (Australia) Pty. Ltd. v Fortescue Metals Group Ltd (No. 3) [2014] WASC 162, at [50]. See Australian Financial Services and Leasing Pty. Ltd. v Hills Industries Ltd. [2014] HCA 14, (2014) 253 C.L.R. 560, at [73]; Mann v Paterson Constructions Pty Ltd [2019] HCA 32, (2019) 373 A.L.R. 1, at [199]. See too K. Barker, "Unjust Enrichment in Australia: What Is(n't) It? Implications for Legal Reasoning and Practice” (2020) 43 Melbourne University L.R. 903. 
enrichment was gained at his expense, and that it was "unjust". ${ }^{98}$ Moreover, the question whether a defendant's enrichment was "unjust" is a legal question that turns on the claimant's ability to bring the facts "within or close to some established category or factual recovery situation": $: 99$ the courts have no "discretionary power to order repayment whenever it seems ... just and equitable to do so". ${ }^{100}$ The claim in Morris was not pleaded like this and the claimant sought to invoke unjust enrichment as a broad principle of justice. Such a pleading would meet with as much judicial disapprobation today as it did in the case.

It seems, too, that in Morris the parties had no shared understanding that the husband would pay for his occupation prior to the granting of the decree absolute. According to Lane J, the wife's failure to ask him to leave before then meant that he had her implicit permission to occupy the property, but not that the parties had an understanding that he would pay her for doing so. This finding would have been fatal to a claim founded on failure of consideration (a reason for restitution to which we shall come in a moment), and as there was no other reason on the facts why the defendant's enrichment might have been unjust, Lane J's conclusion that the wife had no claim in unjust enrichment must have been correct.

This is not to say, however, that a claim for mesne profits can never be successfully formulated as a claim in unjust enrichment. In principle, such claims should succeed where the claimant can establish the three elements of a claim, and recovery is not barred by a defence. By way of example, let us consider the cases where D was a "tolerated trespasser", and ask how these might have been pleaded as a claim in unjust enrichment under the modern law.

As a first step, $\mathrm{C}$ would have to show that $\mathrm{D}$ had been enriched. In cases about the use and occupation of land there are two possibilities: $\mathrm{C}$ might argue that $\mathrm{D}$ was enriched by using the land to generate profits in the form of third party receipts, e.g. by leasing the land to a third party; or C might argue that $\mathrm{D}$ was enriched by acquiring the opportunity to use and occupy the land - the benefit referred to by Buxton L.J. when he said in Lewisham L.B.C. v Masterson that " $[t]$ he benefit that the defendant has received will, in a use and occupation case, be exactly that - the ability to use and occupy the premises." 101 Tolerated trespasser cases fall into the latter class of case - D's enrichment is the opportunity to occupy the property and no question arises of D having used the property commercially to generate third party receipts.

C's next step would be to establish that D's enrichment was acquired at C's expense. Following Investment Trust Companies (in liq.) v H.M.R.C., the rule that a defendant's enrichment must have been acquired at a claimant's expense can now generally be satisfied only where "the claimant [has] directly provided a benefit to the defendant", ${ }^{102}$ a principle which was later extended by the Supreme Court in Prudential Assurance Co. Ltd. v H.M.R.C. ${ }^{103}$ There the court held that in cases of money payment a claimant can recover the face value of the money because the defendant receives this benefit "directly" from the claimant, but cannot recover the value of the opportunity to use the money, quantified as interest, because the defendant only acquires this benefit "indirectly". This is because the opportunity to use the money is "directly" derived from the defendant's failure to repay the face value of the money immediately on receipt and is not "directly" derived from the claimant's payment. ${ }^{104}$ With

98 Banque Financière de la Cité v Parc (Battersea) Ltd. [1999] 1 A.C. 221, 227 (H.L.); Benedetti v Sawiris [2014] A.C. 938, at [10]; Menelaou v Bank of Cyprus U.K. Ltd. [2015] UKSC 66, [2016] A.C. 176, at [18].

${ }^{99}$ Uren v First National Home Finance Ltd. [2005] EWHC 2529 (Ch.), at [16]-[18].

${ }^{100}$ Kleinwort Benson Ltd. v Birmingham C.C. [1997] Q.B. 380, 386 (C.A).

101 (2000) P. \& C.R. 117, 122 (C.A.).

102 [2017] UKSC 29, [2018] A.C. 275, at [50].

103 [2018] UKSC 39, [2019] A.C. 929.

${ }^{104}$ Ibid., at [71]-[74]. 
respect to their Lordships, this analysis was contrived and unconvincing, ${ }^{105}$ and it would be a further false step if it were generalised and treated as a reason for rejecting claims for the value of an opportunity to use land on the basis that the defendant "directly" acquired this opportunity not from the owner but from his own failure to surrender possession. It is therefore a welcome development that Foxton $\mathrm{J}$ has held that Prudential does not apply in cases "where the benefit conferred is not the transfer of property outright, but the transfer of the right of possession (and the concomitant right of use) of property which the transferor is entitled to terminate at will". The judge said that in such cases

it is appropriate to treat each period during which the right of possession and use subsists as an independent transfer of value. That would be consistent with the fact that the objective valuation of the benefit is itself time-dependent (viz a market rate for use for a particular period). That is very different from the position where there is an outright transfer of money or property, which the transferee subsequently uses (in which case the subsequent use of the money or property will not involve a further and independent transfer of value). ${ }^{106}$

If $C$ establishes that $\mathrm{D}$ was enriched at C's expense, C's final step must be to show that D's enrichment is unjust. On the facts of a typical "tolerated trespasser" case, one possibility might be "free acceptance", but it is a controversial question whether that has been, and should be, recognised as a ground for recovery, ${ }^{107}$ and a more promising route would be to rely on "failure of consideration", also known as "failure of basis". The essence of this ground of recovery is that D's enrichment was conditional on the happening of a "promised counterperformance (whether under a valid contract or not), an event or a state of affairs, which failed to materialise". ${ }^{108}$ The "mere failure of an expectation" which motivated C to benefit $\mathrm{D}$ does not suffice to establish a failure of basis, ${ }^{109}$ and "secret" conditions do not count, i.e. C must have told $\mathrm{D}$ the basis on which $\mathrm{C}$ intended to enrich $\mathrm{D}$, it being judged objectively whether a reasonable person in D's position would have understood that D's enrichment was conditional. ${ }^{110}$ For a claim to lie, there must also have been a total and not merely a partial failure of basis, ${ }^{111}$ although there a number of exceptions to this principle, reflecting judicial unhappiness with its continued existence. ${ }^{112}$ Applying these rules to a typical "tolerated

${ }^{105}$ For critical analysis of the reasoning in Prudential, see C. Mitchell, "End of the Road for the Overpaid Tax Litigation?" in D. Clarry (ed.), The UK Supreme Court Yearbook, Volume 9: 2017-2018 (Cambridge, 2019).

106 School Facility Management Ltd. v Governing Body of Christ the King College [2020] EWHC 1118 (Comm.), at [437].

${ }^{107}$ See Goff \& Jones: The Law of Unjust Enrichment chap. 17.

108 Patel v Mirza [2016] UKSC 42, [2017] A.C. 467, at [13].

${ }^{109}$ Eastenders Cash \& Carry plc v Crown Prosecution Service [2014] UKSC 26, [2015] A.C. 1 , at [115].

${ }^{110}$ Burgess v Rawnsley [1975] Ch. 429, 442 (C.A.); Giedo van der Garde B.V. v Force India Formula One Team Ltd. [2010] EWHC 2373 (Q.B.), at [286]. See too Moorgate Capital (Corporate Finance) Ltd. v Sun European Partners L.L.P. [2020] EWHC 593 (Comm.), at [140]: no claim lies where $C$ has no expectation of payment and/or D is "not aware of any contrary expectation".

${ }^{111}$ Whincup v Hughes (1871) L.R. 6 C.P. 78; Goss v Chilcott [1996] A.C. 788, 797-8 9 (P.C.); Roxborough v Rothmans of Pall Mall Australia Ltd. [2001] HCA 68, (2001) 208 C.L.R. 516, at [14]-[24].

${ }^{112}$ See Goff \& Jones: The Law of Unjust Enrichment paras 12.24-12.32. 
trespasser" case, it can be said that although there was no contract between the parties, they had a common understanding that D's occupation was conditional on payment. A total failure of this condition would render D's enrichment unjust and restitution should therefore follow. Problems might arise where D paid C some money, but less than the parties understood should be paid. D might then answer such a claim by pointing to the rule that there must be a "total failure". On some facts, however, C might reply that the parties' bargain was apportioned, i.e. that D's payment related only to one period of D's occupation and that other periods of D's occupation were not paid for at all. ${ }^{113}$

"Tolerated trespasser" cases are not, of course, the only cases where unjust enrichment analysis can explain why D should pay for the authorised occupation of land where C and D had no contract but did have a common understanding that D's occupation should be paid for. These facts have also arisen in cases where $\mathrm{C}$ and $\mathrm{D}$ were negotiating towards a contract but never entered a legally binding agreement and $\mathrm{C}$ let $\mathrm{D}$ occupy the property in the meantime, ${ }^{114}$ and in cases where $C$ and $D$ entered a contract which they believed to be legally valid but which was void for non-compliance with a statute. ${ }^{115}$ In cases of the latter kind, mistake of law might be a viable unjust factor as well as failure of basis. ${ }^{116}$

\section{WHY IT MATTERS}

The foregoing discussion has shown that claimants have often sought to recover "mesne profits", and that judges have often upheld or rejected such claims, without clearly identifying the underlying cause of action. This is to be regretted, because it matters what cause of action a claimant relies on. There are various reasons why this is so.

In the first place, different types of claim have different ingredients that must be pleaded, and evidence must be led to establish that these ingredients are present on the facts of a case. If it is unclear what the cause of action is, it will be unclear whether the facts support the claim. Second, different remedies are awarded in response to different types of claim. Where C's claim is in unjust enrichment, for example, the goal of the remedy is to make D return the value of the benefit that $D$ has unjustly received at C's expense; if C's claim is based on trespass, $\mathrm{C}$ may obtain compensation for the loss that $\mathrm{C}$ has suffered as a result of the wrong, or an award which strips D of the profits that D has obtained from the trespass. We discuss this in a second article, where we examine the remedial possibilities, and emphasise that different rules govern the assessment of different remedies awarded in response to different claims. ${ }^{117}$

Third, English law effectively operates a hierarchy of claims in cases where C and D have a contract. In such cases, the law prevents $\mathrm{C}$ from bringing an action in tort or unjust enrichment, rather than in contract, if this would subvert the parties' agreed allocation of risk

${ }^{113}$ Cf. Fibrosa Spolka Akcyjna v Fairbairn Lawson Combe Barbour Ltd [1943] A.C. 32, 65 (H.L.); Goss v Chilcott [1996] A.C. 788, 798 (P.C.); Roxborough v Rothmans of Pall Mall Australia Ltd. (2001) 208 C.L.R. 516, at [9]-[13], [109], [195]-[196].

114 As in e.g. Lewisham L.B.C. v Masterson (2000) 80 P. \& C.R. 117 (C.A.). Cf. Benedettiv Sawiris [2014] A.C. 938 (services performed in anticipation of a contract that failed to materialise).

${ }^{115}$ As in e.g. Ovidio Carrideo Nominees v The Dog Depot Pty Ltd [2006] VSCA 6, [2006] V. Conv. R. 54-713. Cf. Guinness Mahon \& Co. Ltd. v Kensington and Chelsea R.L.B.C. [1999] Q.B. 215 (C.A.) (payments made under void interest rate swaps contract recoverable on the ground of failure of consideration).

${ }^{116}$ Cf. Kleinwort Benson Ltd v Lincoln C.C. [1999] 2 A.C. 349 (H.L.) (payments made under void interest rate swaps contract recoverable on the ground of mistake of law).

${ }^{117}$ C. Mitchell and L. Rostill, "Making Sense of Mesne Profits: Remedies". 
and reward. ${ }^{118}$ One cannot know if this principle applies in any particular "mesne profits" case unless one knows whether $\mathrm{C}$ and $\mathrm{D}$ had a contract. Fourth, even where there is no contract, so that there is nothing to prevent $\mathrm{C}$ from claiming in tort rather than unjust enrichment or vice versa, C may be forbidden to bring both types of claim if they "overlap". Again, one cannot know how the rules that forbid "overlapping claims" apply in "mesne profits" cases unless one knows which types of claim $\mathrm{C}$ means to bring and which types of remedy are sought. ${ }^{119}$

A fifth reason is that different defences apply to different types of claim. It may be that the change of position defence is available to D where C's claim is based on unjust enrichment, but not where $\mathrm{C}$ claims in tort. ${ }^{120}$ Where a statutory provision renders a lease void, barring a contractual claim on the ground of illegality, $\mathrm{C}$ may still be able to claim in unjust enrichment - whether or not $\mathrm{C}$ can do this will depend on the court's assessment of the policy factors in play. ${ }^{121}$ Where $\mathrm{D}$ invokes a defence of limitation, it may be essential to know if C's claim lies in contract, tort, or unjust enrichment, for example if the relevant limitation rule stipulates that time starts to run when the cause of action accrues. ${ }^{122}$

Sixth, there are many statutes in which rules are laid down with respect to such matters as protection from eviction, housing benefit, compulsory purchase, and so on, where references to "mesne profits" are included, or in some cases deliberately omitted. Interpreting such legislation correctly requires one to know what the legislature understood "mesne profits" to mean in the context of the statutory regime. For example, consider the rules governing housing benefit and now universal credit. These seek to help eligible claimants to pay "rent", but to know whether they also permit claimants to recover payments of "mesne profits" one needs to understand what this expression means. Under the housing benefit regime, "rent" is defined to include "payments by way of mesne profits" and "payments in respect of, or in consequence of, use and occupation of the dwelling". ${ }^{123}$ The Welfare Reform Act 2012 and associated secondary legislation provide for the replacement of various benefits, including housing benefit, with a single monthly payment of universal credit. The housing cost element of an award of universal credit is to include an amount in respect of an eligible claimant's liability to make "rent payments", ${ }^{24}$ including "payments for a licence or other permission to occupy accommodation". ${ }^{125}$ But "mesne profits" and "payments in respect of use and occupation" are

${ }^{118}$ Harro Group Pty Ltd v Aspire Pty Ltd [2019] QSC 189, at [34]-[56].

${ }^{119}$ Recent cases where this has been an issue are Shi v Jiangsu Native Produce Import \& Export Corp. [2009] EWCA Civ 1582 and Ramzan v Brookwide Ltd. [2011] EWCA Civ 985, [2012] 1 All E.R. 903 (C.A.).

${ }^{120}$ Marino v FM Capital Partners Ltd [2020] EWCA Civ 245, [2020] 3 W.L.R. 109 at [49]. For an argument that change of position should be a defence to some torts, see C. Rotherham, "Morally Blameless Wrongdoers and the Change of Position Defence" (2018) 30 Singapore Academy of Law Journal 149; and note Cavenagh Investment Pte. Ltd. v Kaushnik Rajiv [2013] SGHC 45, at [58]-[75] where the defendant was allowed to invoke change of position as a defence to a claim for restitutionary damages for trespass.

${ }^{121}$ Pavey \& Matthews Pty Ltd. v Paul (1987) 162 C.L.R. 221; Patel v Mirza [2017] A.C. 467; Ovidio Carrideo Nominees v The Dog Depot Pty Ltd [2006] V. Conv. R. 54-713, at [11], [21], [32].

${ }^{122}$ In Naylor v Barlow [2019] EWHC 1565 (Ch), [2019] W.T.L.R. 981, at [25], Judge Hodge Q.C. said: "Mesne profits are covered by the six years' period for tort claims in s. 2 [of the Limitation Act 1980]". This will be so, of course, only where C's claim is a claim in tort.

${ }^{123}$ Housing Benefit Regulations 2006 (S.I. 2006/213), reg. 11(1), 12(1).

124 Welfare Reform Act 2012, s. 11; Universal Credit Regulations 2013 (S.I. 2013/376), reg. 25(2)

${ }^{125}$ Universal Credit Regulations 2013 (S.I. 2013/376), sch. 1(2)(b). 
not mentioned in the legislation, and the Department for Work and Pensions has said that such payments were deliberately omitted. ${ }^{126}$ The Department "decided not to carry forward specific provisions for mesne profits as it would not be fair for the benefit system to underwrite such arrangements." 127 The significance of this reform cannot be properly assessed unless one knows how to differentiate, in the context of the legislative scheme, a "claim for mesne profits", "a claim in respect of use and occupation", and "a claim in respect of a licence to occupy." And one cannot do this unless one knows how such claims are understood under the general law and what the causes of action are which underpin each type of claim.

\section{CONCLUSION}

This article has concerned a body of cases concerning claims that property lawyers have fallen into the unreflecting habit of lumping together and describing as "claims for mesne profits". We have argued that this language conceals more than it reveals and that to understand such claims one must identify the causes of action on which they are founded. Only by doing this can one understand the different reasons why they should succeed in different situations, the different ways in which they should be pleaded, the different evidence which is needed to show that a claim is a good one, and the different principles which should govern the assessment of awards made to successful claimants.

Readers who are persuaded by these arguments may already have drawn the conclusion for themselves that the law would be better off without the term "mesne profits". This may lead them to ask why we chose to treat all the cases where this language has been used as if they were a unified object of analysis. Given our argument that the cases do not form a coherent category, it might be asked, why did we take them as the starting point for our study? We would answer that we have sought to explain the law as we have found it, to discover how its present muddled state came about - and to argue by way of conclusion that the various principles by which it is governed would indeed be easier to understand if lawyers thought and spoke about it differently. If the terminology of "claims for mesne profits" were abandoned and lawyers referred instead to claims founded on the tort of trespass, claims founded on contract and claims founded on unjust enrichment, then we believe that would be a change for the better. It would help everyone see more clearly what the "mesne profits" cases are about.

It would also make it easier to recognise commonalities (and to avoid drawing inapt analogies) between cases to which the label "mesne profits" has been attached and other groups of cases. For example, it would then be easier to understand that "mesne profits" claims founded on trespass to land to recover the value of an opportunity to use and occupy land are on all fours with claims founded on trespass to goods to recover the value of an opportunity to use the goods; ${ }^{128}$ that claims for "mesne profits" that seek to enforce, or recover damages for breach of, a contractual obligation to pay for the occupation of land are akin to claims to enforce, or recover damages for breach of, a contractual obligation to pay a licence fee for the reproduction of works protected by copyright; and that claims for "mesne profits" founded on

${ }^{126}$ Department of Work and Pensions, Universal Credit and Related Regulations: Response to SSAC Technical Comments and Policy Points, para. 26 of the "Response to Policy Points"; published online:

https://assets.publishing.service.gov.uk/government/uploads/system/uploads/attachment_data /file/324545/ssac-uc-technical-annex-dwp-response.pdf

127 Ibid.

${ }^{128}$ Cf. Inverugie Investments Ltd. v Hackett [1995] 1 W.L.R. 713, 718 (P.C.), where Lord Lloyd analogised between the opportunity to use a concrete mixer and the opportunity to use residential property. 
unjust enrichment to recover the value of an opportunity to use and occupy land acquired during failed negotiations for the granting of a lease resemble claims founded in unjust enrichment for the value of work done in anticipation of a contract for services that fails to materialise. 